DOI: https://doi.org/10.15407/techned2018.05 $: 116$

\title{
USE OF AUTONOMOUS MEASURING SYSTEMS FOR DIAGNOSING OF ELECTRICAL EQUIPMENT WITH REGARD TO ITS OPERATING MODES
}

Journal

Publisher

ISSN

Issue

Pages
Tekhnichna elektrodynamika

Institute of Electrodynamics National Academy of Science of Ukraine 1607-7970 (print), 2218-1903 (online)

No 5, 2018 (September/October)

$116-120$

\section{Authors}

S.M. Gertsyk, Y.I. Gyzhko*, V.M. Zvarich**, M.V. Myslovych ${ }^{\star \star *}$, L.B. Ostapchuk, R.M. Sysak

Institute of Electrodynamics National Academy of Sciences of Ukraine,

pr. Peremohy, 56, Kyiv, 03057, Ukraine,

e-mail: sergey.gertsik@gmail.com; yuriy.gyzhko@gmail.com; mysl@ied.org.ua;

rsysak@ied.org.ua

* ORCID ID : http://orcid.org/0000-0002-5702-4738

** ORCID ID : http://orcid.org/0000-0002-1271-4954

*** ORCID ID : http://orcid.org/0000-0002-6245-7917

**** ORCID ID : http://orcid.org/0000-0003-4474-4776

The structure of the diagnostic system is proposed, in which the Energy Harvesting (EN) technology is used to provide the functioning of autonomous measuring transducers located on the parts of the electric machines (EM), which provides an opportunity to provide the power supply of electronic circuits in autonomous vibration measurement devices by converting into electric current of the mechanical energy of the vibration of the EM unit. On the examples of studying the vibrations of the charged magnetic circuit, the necessity of forming the spaces of diagnostic features is taken into account, taking into account the operating modes of the objects 
being studied. The obtaining of experimental data is carried out using a laboratory sample of the diagnostic system, which includes measuring transducers, the functioning of which is provided by autonomous power systems. References 10, figures 3, tables 2 .

Key words: electrotechnical equipment, operating modes, autonomous measuring converters.

Received: 02.03 .2018

Accepted: 03.05 .2018

Published: 16.08 .2018

\section{References}

1. Babak S.V., Myslovich M.V., Sysak R.M. Statistical diagnostics of electrical equipment. K.: Institute elektrodinamiki NAN Ukrainy, 2015. 456 p. (Rus)

2. Birger I.A. Technical diagnostics. Moskva: Mashinostroenie, 1978. 211 p. (Rus)

3. Gertsik S.M., Gyzhko Y.I., Myslovich M.V., Ostapchuk L.B., Sysak R.M. Algorithms of functioning and software of the multi-level monitoring system of the state and technical diagnostics of the equipment of the objects of the electric power industry. Tekhnichna Elektrodynamika

2016. No 4. Pp. 86 - 88. (Ukr) DOI:

https://doi.org/10.15407/techned2016.04.086

4. Gyzhko Y.I., Myslovich M.V. Elements of the theory and questions of practical application of systems of vibration diagnostics of moving parts of electric machines. Tekhnichna

Elektrodynamika

No 2. Pp. 45 - 56. (Ukr)

5. Ermolin N.P., Zherikhin I.P. Reliability of electrical machines. Leningrad: Energiia, 1976. 248

p. (Rus)

6. Kuzmin V.V., Livshits A.L., Shpatenko V.S. Low-cost and energy-saving technologies for the 
rehabilitation of turbo-generators are the basis for the technical re-equipment of the energy sector of Ukraine. Elektromekhanichni i enerhozberihaiuchi systemy. 2011. No 2. Pp. 90-92. (Rus)

7. Klyuyev V.V., Parkhomenko P.P. Technical means of diagnosis. Moskva: Mashinostroenie, 1989. 672 p. (Rus)

8. Evanczuk S. Energy Scavenging with Piezoelectric Transducers. URL: https://www.digikey. com/en/articles/techzone/2011/nov/energy-scavenging-with-piezoelectric-transducers (application date 15.01.2018).

9. MIDE Engineering Solutions. URL: https://www.mide.com (application date 15.01.2018). 10. V21BL Product Overview. URL: https://www.digikey.com/product-detail/en/mide-technolo gy-corporation/ V21BL/V21BL-ND/2402860 date 15.01.2018). 